\title{
Genetic interrelationship among tepary bean (Phaseolus acutifolius A. Gray) genotypes revealed through SSR markers
}

\author{
Zinhle Babongile Mhlaba ${ }^{1}$, Beyene Amelework ${ }^{2}$, Hussein A. Shimelis ${ }^{1,2}$, Albert Thembinkosi Modi $^{1}$, Jacob \\ Mashilo* ${ }^{1,2}$ \\ ${ }^{1}$ University of KwaZulu-Natal, School of Agricultural, Earth and Environmental Sciences, Discipline of Crop Science, \\ Private Bag X01, Scottsville 3209, Pietermaritzburg, South Africa \\ ${ }^{2}$ University of KwaZulu-Natal, African Centre for Crop Improvement (ACCI), Private Bag X01, Scottsville 3209, \\ Pietermaritzburg, South Africa
}

\section{*Corresponding author: jacobmashilo@yahoo.com}

\begin{abstract}
Tepary bean (Phaseolus acutifolius A. Gray) is one of the useful plant genetic resources possessing novel genes for abiotic and biotic stress tolerance. It is largely used in the breeding of common bean or related tropical legumes. The objective of this study was to determine the genetic interrelationship present among 20 diverse tepary bean genotypes using 10 selected and polymorphic simple sequence repeat (SSR) markers and to identify genetically unique parental lines for developing breeding populations. The SSR markers amplified a total of 57 putative alleles with a size range of 102 to 304 base pairs. Number of alleles ranged from 2 to 16 with a mean of 5.7 per locus. Number of effective alleles ranged from 1.5 to 11.6 with a mean of 4.32 . The mean observed and expected heterozygosity were 0.45 and 0.51 , respectively, reflecting moderate level of genetic interrelationship among the tested genotypes. The mean polymorphic information content (PIC) of the SSR loci was 0.50 suggesting that the selected markers had high discriminatory power for genetic diversity analysis of tepary bean. Genetic distances varied from 0.18 to 0.64 with a mean value of 0.42 , signifying relatively low levels of genetic diversity among the studied genotypes. Cluster analysis grouped the genotypes into three distinct genetic groups. Unique genotypes such as G40201, G40237, G40158, G40157 and G40158 from Cluster I, G40084 and G40033 from Cluster III were selected. These are distantly related parents and recommended for further breeding or genetic recombination to broaden the genetic basis of tepary bean or related legumes.
\end{abstract}

Keywords: breeding, legume, $P$. acutifolius, tepary bean, microsatellite markers.

Abbreviations: CTAB_mixed alkyltrimethyl-ammonium bromide protocol; $\mathrm{H}_{\mathrm{o} \_}$observed heterozygosity; $\mathrm{H}_{\mathrm{e} \_}$expected heterozygosity; SSRs_simple sequence repeats; UPGMA_unweighted pair group method using arithmetic averages.

\section{Introduction}

Tepary bean (Phaseolus acutifolius A. Gray) belonging to the genus Phaseolus is a diploid $(2 \mathrm{n}=2 \mathrm{x}=22)$ and predominantly self-fertilizing crop (Schinkel and Gepts, 1988). Tepary bean is originated from arid and semi-arid regions of north-western Mexico and south-western United States (Blair et al., 2002; Garvin and Weeden, 1994). Tepary bean has unique genetic attributes such as tolerance to drought, heat and salt stress making it an ideal crop for cultivation in arid and semi-arid environments (Rao et al., 2013; Porch et al., 2013a). Four botanical varieties (var.) of tepary bean are recognized including var. acutifolius, var. latifolius, var. tenuifolius (Buhrow, 1983; Blair et al., 2012; Gujaria-Verma et al., 2016). Further, the species $P$. parvifolius is reportedly genetically related to $P$. acutifolius and morphologically identical to var. tenuifolius (Freytag and Debouck, 2002; Muñoz et al., 2006). The cultivated tepary bean is believed to be a descendant of the wild var. acutifolius (Muñoz et al., 2006). The grain of tepary bean contains high protein content of $24 \%$, essential mineral elements (e.g. $\mathrm{Ca}, \mathrm{Mg}, \mathrm{Cu}, \mathrm{Fe}, \mathrm{K}, \mathrm{Mn}, \mathrm{S}, \mathrm{Zn}$ ), oil and $33 \%$ saturated fatty acids, $67 \%$ unsaturated fatty acids, $24 \%$ monounsaturated fatty acids and $42 \%$ polyunsaturated fatty acids (Amarteifio and Moholo, 1998; Bhardwaj and Hamama, 2004; 2005). In some instances, the crop is grown as leafy vegetable and the haulms are used for animal feed (Molosiwa et al., 2014). Tepary bean has high level of resistance to bean weevil caused by Acanthoscelides obtectus (Kusolwa and Myers, 2011), common bacterial blight [Xanthomonas campestris (axonopodis) pv. Phaseoli] (Singh and Muñoz, 1999; Miklas et al., 2006), rust (Uromyces phaseoli), anthracnose (Colletotrichum lindemuthianum), angular leaf spot (Isariopsis griseola) (Pratt and Nabhan, 1988; Thomas et al., 1983) and bean golden mosaic virus (Miklas and Santiago, 1996). Owing to the various desirable attributes, tepary bean genetic resources are recommended for production under harsh growing environments and some useful genes are transferred into common bean (Tar'an et al., 1998; Liu et., 2008; Beebe et al., 2013). It has been 
successfully used to develop advanced breeding lines of common bean with enhanced level of drought tolerance through genomic introgression. So far, $25 \%$ of the tepary genome has been introgressed into common bean (Muñoz et al. 2004).

Tepary bean is cultivated in South Africa but is a neglected and under-researched crop compared to other legumes such as common bean, cowpea, and Bambara groundnut. There is no dedicated tepary bean breeding program in South Africa to release varieties with tolerance to drought, pest and disease resistance. The crop has considerable potential as an alternative future food security crop and can be exploited by legume breeding programs in South Africa. To cultivate tepary bean in semi-arid and unfavourable environments outside of the centre of diversity, legume breeders at the International Center for Tropical Agriculture (CIAT)-Columbia are developing candidate genotypes. These genotypes can be selected in target growing environments to identify welladapted and high yielding candidates. An attempt was made to introduce and select heat and drought tolerant tepary bean genotypes developed by CIAT in South Africa to design, develop and deploy improved cultivars. Well-characterised and genetically unique tepary bean germplasm is a prerequisite to develop locally adapted and superior cultivars.

Genetic diversity analysis is an important step in plant breeding programs to identify genetically unique and complementary parental genotypes. These will also enable to create variability for further selection and to introgress desirable genes from diverse germplasm into the cultivated genotypes. Effective genetic grouping requires utilization of robust and informative DNA markers. Several studies have determined the level of genetic diversity in tepary bean. Muñoz et al. (2004) used amplified fragment length polymorphism (AFLP) markers and reported that $P$. parvifolius was genetically distinct from $P$. acutifolius. Blair et al. (2012) assessed genetic diversity in tepary bean accessions using SSR markers and reported that genetic differentiation was relatively higher in wild than cultivated tepary beans. Gujaria-Verma et al. (2016) reported genetic diversity using single nucleotide polymorphism (SNPs) markers.

There are limited genomic resources currently available for genetic analysis of tepary bean and only 54,917 tepary bean expressed sequence tags (EST) are currently available publicly (Gujaria-Verma et al., 2016). Further, only two genetic linkage maps based on AFLP and SNPs have been developed for tepary bean (Muñoz et al. 2004; GujariaVerma et al., 2016). There are no SSR markers developed specifically for the crop; however, SSR markers developed for common bean serve as important genomic resources for genetic diversity analysis and breeding in tepary bean (Blair et al., 2003; 2012). Simple sequence repeats (SSRs) markers are currently the most-suitable markers for germplasm characterization (Varshney et al., 2005), genome-wide analysis (Blair et al., 2012), gene tagging and gene mapping (Peng et al., 1999) in diverse crop species. SSR markers are PCR-based, co-dominant, locus-specific, highly reproducible, polymorphic, informative and relatively simple to use (Xu et al., 2014). The objective of this study was to determine the genetic interrelationship present among 20 diverse tepary bean genotypes using 10 selected and polymorphic simple sequence repeat (SSR) markers and to identify genetically unique parental lines for developing breeding populations.

\section{Results}

\section{Polymorphism and allelic diversity of SSR markers}

The estimated genetic parameters are presented in Table 3. The SSR markers detected a total of 57 putative alleles with a size range of 102 to 304 base pairs (bp). The number of alleles $\left(N_{\mathrm{a}}\right)$ detected per locus across the 20 tepary bean genotypes ranged from 2 (for marker BMD28) to 16 (PVAT007), with a mean of 5.7 alleles per locus. Three out of the ten SSR primers (BM053, BM152 and BM210) were monomorphic. The number of effective alleles per locus ranged from 1.54 to 11.59 with a mean of 4.32 alleles per locus. The lowest number of effective alleles $\left(N_{\mathrm{e}}\right)$ was observed for loci BMD053, BM152 and BM210 (1.00) and the highest for PV-AT007 (11.59). Fixation index $\left(F_{\mid S}\right)$ exhibited contrasting values ranging from -0.12 to 1.00 with a mean of 0.06 . F represents the average deviation of the population's genotypic proportions from Hardy-Weinberg equilibrium for a locus. A negative $F$ value represents an excess of heterozygotes. The polymorphic information content (PIC) ranged from 0.35 for BMD28 and 0.97 for PVAT007. The mean PIC of the seven polymorphic primers was 0.73. In the present study six SSR markers used had PIC values $>0.60$, suggesting adequate discriminatory power of the SSR loci used in the current study. These were further classified as informative markers to establish the genetic relationship among tepary bean genotypes. Observed heterozygosity $\left(H_{0}\right)$ ranged from 0.00 (GATS91) to 1.00 (BMD1, BM154 and BM199), with a mean of 0.45. Gene diversity $\left(H_{e}\right)$ ranged from 0.36 (MBD28) to 0.94 (PV-AT007) with a mean of 0.51 , suggesting that $51 \%$ of the individuals are expected to be heterozygous at a given locus under random mating conditions. Major alleles ranged from 102 for marker BM152 to 289 for marker BM199. Major allele frequency ranged from 0.13 for marker BM199 to 1.00 for markers BM152 and GATS91.

\section{Genetic relationships among tepary bean genotypes}

To evaluate the genetic relationships among the tepary bean genotypes, a dendogram based on neighbor-joining algorithm using the unweighted pair group method using arithmetic average was constructed (Fig. 1). The tested tepary bean genotypes were grouped into three distinct clusters. The distinctiveness of the clusters was confirmed by a highly significant cophenetic correlation coefficient $(r=$ 0.96; $P<0.001$ ). Cluster I comprised of 8 genotypes which originated from Mexico except G40201. Two of the genotypes (e.g. G40157 and G40158) in Cluster I have a prostrate-indeterminate growth habit, while the rest are climbing types. Cluster II comprised of three genotypes that have climbing growth habit with white and opaque seed. Cluster III comprised of 9 genotypes which originated from Mexico and the United States and have a climbing growth habit. The seed coat colours of the genotypes belonging in Cluster III are either white or cream except for genotypes G40068 (yellow) and G40066A (pink). Genetic distance (GD) measured among the genotypes based on Jaccard's genetic distance revealed large genetic variations among the genotypes (Fig. 2). The genetic distance values showed a normal distribution with $68 \%$ of the values lying between \pm 1 standard deviation. The GD values varied from 0.18 to 0.64 , 
with a mean value of 0.42 , suggesting moderate genotypic differentiation (Table 4). The highest genetic distance was found between $\mathrm{G} 40084$ with $\mathrm{G} 40158$ (GD = 0.64), G40237 $(G D=0.63), G 40148(G D=0.60), G 40201(G D=0.63)$ and G40157 (GD = 0.62). G40084 was grouped in Cluster III, whereas the rest of the genotypes were grouped in Cluster I. Genotype G40033 was genetically distant from G40201, G40157 and G40066A with GD values > 0.50. G40033 was grouped in Cluster III; whereas, G40201 and G40157 were grouped in Cluster I, except G40066A which grouped in Cluster III. Genotype G40084 was distant from G40066A with a GD value of 0.63 (Table 4).

\section{Discussion}

Tepary bean is an important but under-utilized legume crop possessing novel genes for abiotic and biotic stress tolerance breeding in common bean or related tropical legumes (Souter et al., 2017). Understanding genetic relationships among diverse tepary bean genetic resources is essential to facilitate effective breeding. The present study examined genetic relationships among 20 tepary bean genotypes using SSR markers in order to identify genetically unique parental lines for developing tepary bean breeding populations. Initially 50 diverse tepary genotypes were acquired from International Center for Tropical Agriculture (CIAT)Columbia. Preliminary field and greenhouse evaluations (data not presented) under South African conditions indicated that some 20 genotypes were agronomically suitable with better yield and yield-related traits. These genotypes were selected and subjected to genetic analysis to select genetically distinct ones for effective breeding.

The SSR markers generated a total of 57 putative alleles of different fragment size ranging from 102 to 304 base pairs (Table 3). The number of alleles ranged from 1 to 16 with a mean of 5.7 alleles per locus. This was lower than the 8.3 alleles detected by Blair et al. (2012) when evaluating 140 tepary bean genotypes using 20 SSR markers. Further, Blair et al. (2006) reported a mean value of 7.8 alleles per locus in 43 common bean genotypes which was higher than the current findings. The number of effective alleles ranged from 1.0 to 11.59 , with a mean value of 4.32 . The polymorphic information content which is a measure of allelic diversity based on allele frequency (Smith et al., 2000) ranged from 0.00 to 0.97 with a mean of 0.52 (Table 3). The mean PIC value in the current study was comparable to those reported in other cultivated legumes including common bean (Blair et al., 2006), soybean (Chauhan et al., 2015), cowpea (Ali et al., 2015), groundnut (Otenga-Frimpong et al., 2015) and faba bean (Rebaa et al., 2017). Three of the genomic microsatellites (e.g. BM053, BM152 and BM210) amplified only one band suggesting these gene-based markers were highly monomorphic (Table 3). However, by disregarding the monomorphic genomic SSRs, the mean PIC value for $70 \%$ of the markers was 0.71 , suggesting adequate discriminatory power of the common bean SSR markers useful to detect differences among the tested tepary bean genotypes. The discriminatory power of these loci has also been reported previously in common and tepary bean (Blair et al., 2006; 2012; Diaz and Blair, 2006). A mean heterozygosity $\left(H_{0}\right)$ value of 0.45 was recorded in this study suggesting that almost half of the loci were heterozygous and the remaining half of the loci reached acceptable level of homozygosity.
However, the mean gene diversity $\left(H_{\mathrm{e}}\right)$ was 0.51 , reflecting moderate level of genetic interrelationship among the tested tepary bean genotypes. The relatively low genetic diversity observed in this study agrees with previous reports that suggested tepary bean has a narrow genetic base (Blair et al., 2012). This is partly attributed to natural and artificial selection exerted during long-term domestication of a limited genetic of pool of the crop (Schinkel and Gepts, 1988). In the past, tepary bean production was practiced in its centre of origin or diversity mainly in isolated geographic regions notably in drier parts of Mexico and the USA. This has probably localised its centre of domestication and hence rendered low adaptation and genetic differentiation of the crop (Freytag and Debouck, 2002). Further, tepary bean has low out-crossing rate with limited natural cross pollination and genetic recombination. This has probably partially contributed to the low genetic variation and limited genetic base of the crop (Blair et al., 2012).

The UPGMA derived dendogram using SSR markers classified the tepary bean genotypes into three main genetic clusters (Fig. 1). A cophenetic correlation coefficient between the genetic similarity matrix and the cluster analysis was 0.96 , indicating a distinct clustering structure and a very high goodness of fit of the clustering based on the original distance matrix (Dias et al., 2008; Mujaju et al., 2011). The current study revealed that most tepary bean genotypes were grouped based on their region of origin and morphological traits suggesting that the test genotypes share similar genetic backgrounds. For example, genotypes in Cluster I originated from Mexico, whereas those in Cluster III originated from Mexico and the USA. Further, most of the genotypes in Cluster I have a prostrate-indeterminate growth habit, while the rest are climbing types. Genotypes in Cluster III were either white or cream except for genotypes G40068 and G40066A which have a yellow and pink seed coat colours, respectively. Schinkel and Gepts (1988) reported similar pattern of genetic grouping based on geographical origin and morphological traits. In their study, tepary bean genotypes with and without basal lobed leaflet type originated from the USA and Mexico, respectively and were grouped independently. Tepary bean is originated from the USA and Mexico and results of the current study confirmed the possibility and agreeing with Gujaria-Verma et al. (2016) who reported that tepary bean genotypes were grouped based on geographic origin.

The genetic distance in the current study varied from 0.18 to 0.64 , with a mean value of 0.43 , suggesting moderate genetic differentiation among the studied tepary bean genotypes. Previous studies using SSR markers and SNPS have focused on genetic differentiation (e.g. population structure analysis) among different varieties of tepary bean (Blair et al., 2012; Gujaria-Verma et al., 2016) with very little information reported on genetic distances between genotypes. Such information is important to identify genetically distant parental lines that can be used to conduct crosses aimed at developing novel breeding populations. In the current study, genotypes G40084 and G40158, G40237 G40148 and G40157 displayed the highest genetic distance and were grouped in different clusters (Table 4; Fig. 1). Further, genotype G40033 allocated in Cluster III was distantly related to G40201 and G40157 allocated in Cluster I. The identified genotypes especially from unrelated genetic groups exhibiting high genetic distances will aid in the 
Table 1. Description of tepary bean genotypes used in the study with geographic origin, growth habit and grain characteristics.

\begin{tabular}{|c|c|c|c|c|c|}
\hline No & Genotype & Country of origin & Growth habit & Seed colour & Seed brightness \\
\hline 1 & G40033 & Mexico & Climbing & Cream & Opaque \\
\hline 2 & G40001 & Mexico & Climbing & White & Opaque \\
\hline 3 & G40084 & Mexico & Climbing & Cream, Brown & Opaque \\
\hline 4 & G40111 & Mexico & Climbing & Black, Cream & Opaque \\
\hline 5 & G40125 & Mexico & Climbing & White & Intermediate \\
\hline 6 & G40135A & Mexico & Climbing & White & Opaque \\
\hline 7 & G40144A & Mexico & Climbing & Cream & Intermediate \\
\hline 8 & G40173A & Mexico & Climbing & Yellow & Opaque \\
\hline 9 & G40237 & Mexico & Climbing & Cream & Intermediate \\
\hline 10 & G40148 & Mexico & Prostrate-Indeterminate & White & Opaque \\
\hline 11 & G40157 & Mexico & Prostrate-Indeterminate & White & Opaque \\
\hline 12 & G40158 & Mexico & Prostrate-Indeterminate & White & Opaque \\
\hline 13 & G40023 & United States of America & Climbing & White & Opaque \\
\hline 14 & G40042 & United States of America & Climbing & White & Opaque \\
\hline 15 & G40063 & United States of America & Climbing & White & Opaque \\
\hline 16 & G40066A & United States of America & Climbing & Pink & Opaque \\
\hline 17 & G40068 & United States of America & Climbing & Yellow & Opaque \\
\hline 18 & G40069 & United States of America & Climbing & White & Opaque \\
\hline 19 & G40201 & Costa Rica & Prostrate-Indeterminate & Black, Cream & Opaque \\
\hline 20 & G40064 & United States of America & Climbing & White & Opaque \\
\hline
\end{tabular}

Table 2. Descriptions of the simple sequence repeat (SSR) markers used for genetic differentiation of tepary bean genotypes.

\begin{tabular}{|c|c|c|c|}
\hline Marker name & Primer sequence & Marker type & PIC \\
\hline \multirow[t]{2}{*}{ PV-AT001 } & F: GAGGGTGTTTCACTATTGTCACTGC & Gene-based & $0.94^{(1)}$ \\
\hline & R: TTCATGGATGGTGGAGGAACAG & & \\
\hline \multirow[t]{2}{*}{ PV-AT007 } & F: AGTTAAATTATACGAGGTTAGCCTAAATC & Gene-based & 0.94 \\
\hline & R: CATTCCCTTCACACATTCACCG & & \\
\hline \multirow[t]{2}{*}{ BMD1 } & F: CAAATCGCAACACCTCACAA & Gene-based & 0.94 \\
\hline & R: GTCGGAGCCATCATCTGTTT & & \\
\hline \multirow[t]{2}{*}{ BMD28 } & F: TGCATCAACTTTAGGAGCTTG & Gene-based & 0.87 \\
\hline & R: TCTTGTCTTATCAGCAGGTGGA & & \\
\hline \multirow[t]{2}{*}{ BM053 } & F: TGCTGACCAAGGAAATTCAG & Genomic & 0.92 \\
\hline & R: GGAGGAGGCTTAAGCACAAA & & \\
\hline \multirow[t]{2}{*}{ BM152 } & F: AAGAGGAGGTCGAAACCTTAAATCG & Genomic & 0.89 \\
\hline & R: CCGGGACTTGCCAGAAGAAC & & \\
\hline \multirow[t]{2}{*}{ BM154 } & F: TCTTGCGACCGAGCTTCTCC & Genomic & 0.94 \\
\hline & R: CTGAATCTGAGGAACGATGACCA & & \\
\hline \multirow[t]{2}{*}{ BM199 } & F: AAGGAGAATCAGAGAAGCCAAAAG & Genomic & 0.91 \\
\hline & R: TGAGGAATGGATGTAGCTCAGG & & \\
\hline \multirow[t]{2}{*}{ BM210 } & F: ACCACTGCAATCCTCATCTTTG & Genomic & 0.88 \\
\hline & R: CCCTCATCCTCCATTCTTATCG & & \\
\hline \multirow[t]{2}{*}{ GATS91 } & F: GAGTGCGGAAGCGAGTAGAG & Genomic & 0.91 \\
\hline & R: TGTCACCTCTCTCCTCCAAT & & \\
\hline
\end{tabular}




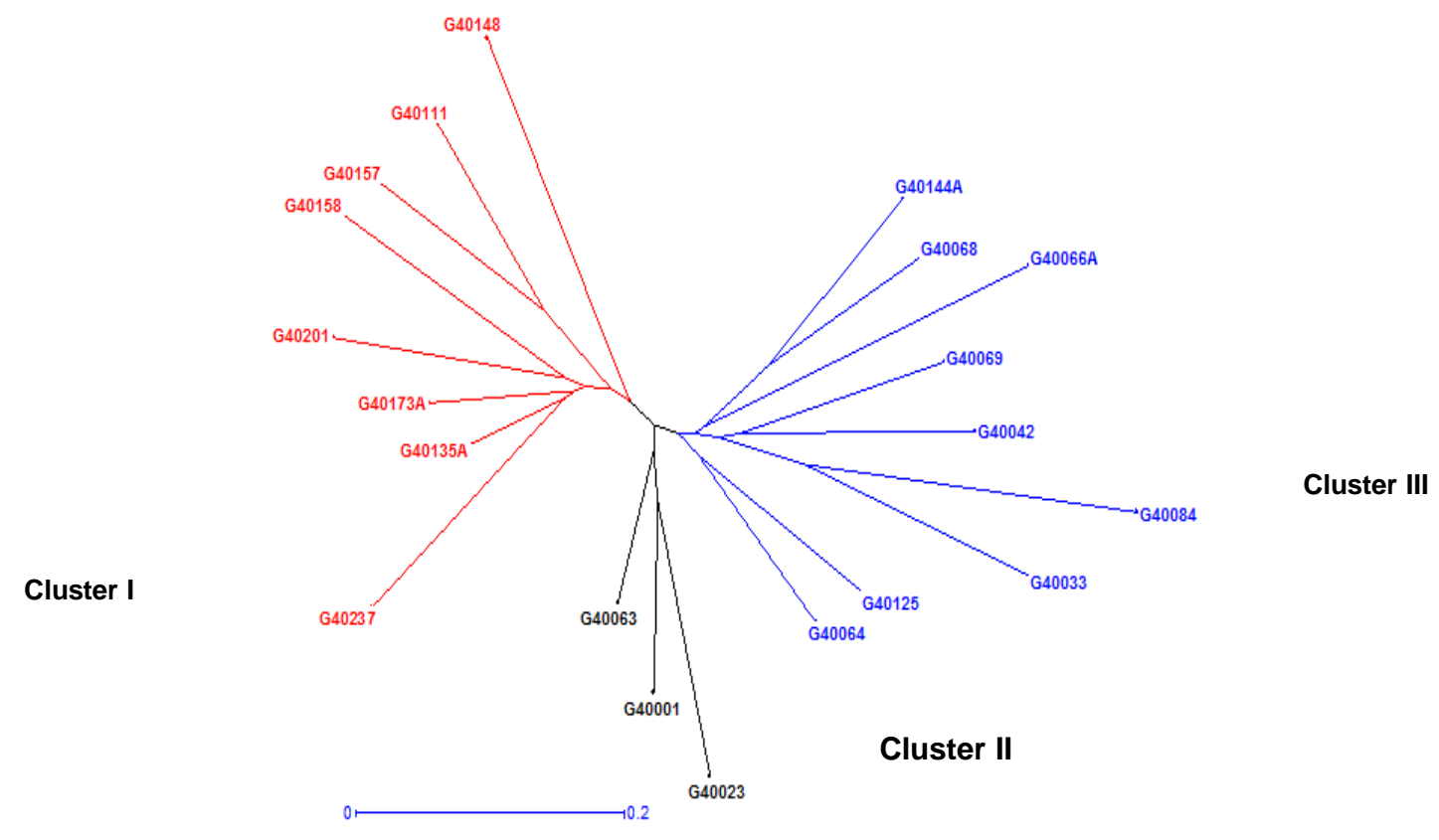

Fig 1. Neighbor joining dendrogram using the unweighted pair group method using arithmetic average based on Jaccard's dissimilarity matrix showing genetic relationships among 20 genetically diverse tepary bean genotypes. Note that different colour represent different groups.

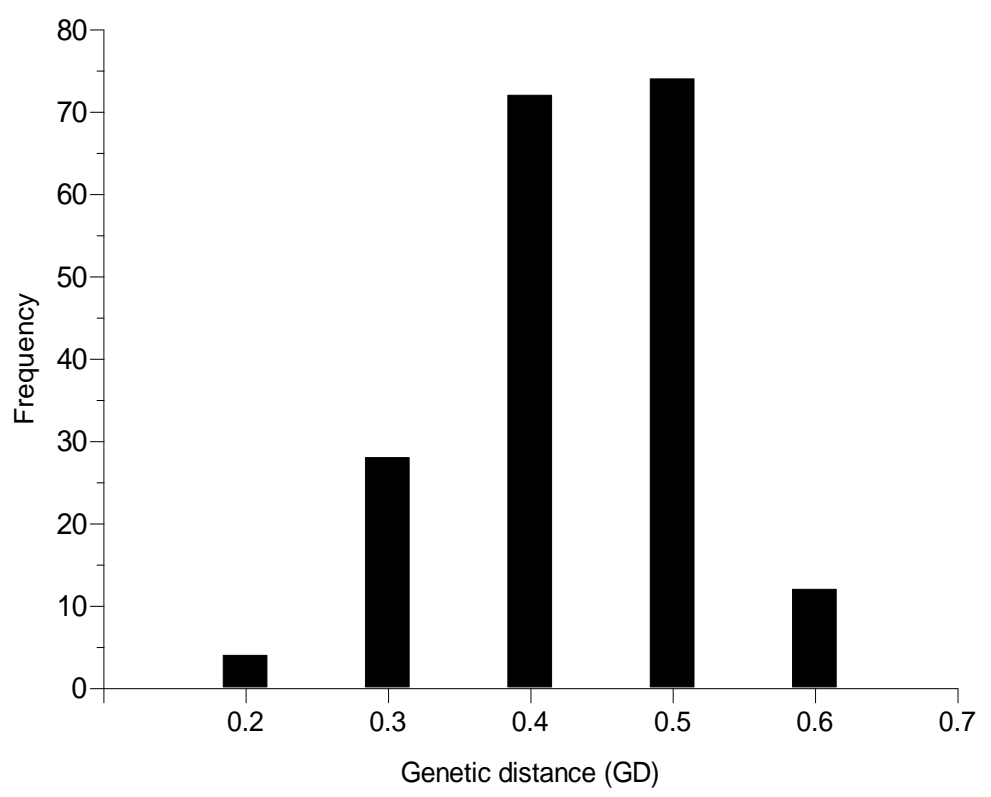

Fig 2. The frequency of tepary bean genotypes (5) based on genetic distance estimates using SSR markers. 
Table 3. Genetic parameters estimated by SSR markers among tepary bean genotypes.

\begin{tabular}{|c|c|c|c|c|c|c|c|c|}
\hline Loci & $\mathrm{N}_{\mathrm{a}}^{(1)}$ & $\mathrm{N}_{\mathrm{e}}$ & $\mathrm{H}_{\mathrm{o}}$ & $\mathrm{H}_{\mathrm{e}}$ & $\mathrm{F}_{\mathrm{IS}}$ & PIC & $\mathrm{M}_{\mathrm{A}}$ & $A_{F}$ \\
\hline PV-AT001 & 5 & 2.7 & 0.56 & 0.65 & 0.12 & 0.63 & 173 & 0.53 \\
\hline PV-AT007 & 16 & 11.59 & 0.7 & 0.94 & 0.23 & 0.97 & 222 & 0.15 \\
\hline BMD1 & 3 & 2.31 & 1 & 0.58 & -0.77 & 0.57 & 181 & 0.42 \\
\hline BMD28 & 2 & 1.54 & 0.25 & 0.36 & 0.28 & 0.35 & 186 & 0.5 \\
\hline BM053 & 1 & 1 & 0 & 0 & - & 0 & 114 & 0.78 \\
\hline BM152 & 1 & 1 & 0 & 0 & - & 0 & 102 & 1 \\
\hline BM154 & 6 & 3.86 & 1 & 0.76 & -0.35 & 0.75 & 230 & 0.35 \\
\hline BM199 & 10 & 9.52 & 1 & 0.92 & -0.12 & 0.94 & 289 & 0.13 \\
\hline $\mathrm{BM} 210$ & 1 & 1 & 0 & 0 & - & 0 & 156 & 0.2 \\
\hline GATS91 & 12 & 8.7 & 0 & 0.91 & 1 & 0.95 & 165 & 1 \\
\hline Overall mean & 5.7 & 4.32 & 0.45 & 0.51 & 0.06 & 0.53 & - & - \\
\hline SE & 1.67 & 1.28 & 0.14 & 0.12 & 0.18 & 0.13 & - & - \\
\hline
\end{tabular}

Table 4. Genetic distance estimates among 20 tepary bean genotypes using SSR markers.

\begin{tabular}{|c|c|c|c|c|c|c|c|c|c|c|c|c|c|c|c|c|c|c|c|c|}
\hline Genotype & $1^{(1)}$ & 2 & 3 & 4 & 5 & 6 & 7 & 8 & 9 & 10 & 11 & 12 & 13 & 14 & 15 & 16 & 17 & 18 & 19 & 20 \\
\hline \multicolumn{21}{|l|}{1} \\
\hline 2 & 0.28 & & & & & & & & & & & & & & & & & & & \\
\hline 3 & 0.48 & 0.48 & & & & & & & & & & & & & & & & & & \\
\hline 4 & 0.42 & 0.42 & 0.43 & & & & & & & & & & & & & & & & & \\
\hline 5 & 0.18 & 0.35 & 0.42 & 0.35 & & & & & & & & & & & & & & & & \\
\hline 6 & 0.26 & 0.41 & 0.48 & 0.35 & 0.26 & & & & & & & & & & & & & & & \\
\hline 7 & 0.48 & 0.54 & 0.56 & 0.43 & 0.42 & 0.48 & & & & & & & & & & & & & & \\
\hline 8 & 0.42 & 0.42 & 0.36 & 0.36 & 0.35 & 0.35 & 0.43 & & & & & & & & & & & & & \\
\hline 9 & 0.38 & 0.39 & 0.46 & 0.33 & 0.32 & 0.32 & 0.52 & 0.46 & & & & & & & & & & & & \\
\hline 10 & 0.54 & 0.54 & 0.43 & 0.50 & 0.48 & 0.48 & 0.63 & 0.57 & 0.46 & & & & & & & & & & & \\
\hline 11 & 0.44 & 0.45 & 0.52 & 0.52 & 0.38 & 0.44 & 0.46 & 0.46 & 0.43 & 0.52 & & & & & & & & & & \\
\hline 12 & 0.35 & 0.47 & 0.42 & 0.36 & 0.28 & 0.28 & 0.48 & 0.36 & 0.39 & 0.54 & 0.45 & & & & & & & & & \\
\hline 13 & 0.40 & 0.46 & 0.42 & 0.42 & 0.33 & 0.40 & 0.48 & 0.27 & 0.44 & 0.54 & 0.50 & 0.35 & & & & & & & & \\
\hline 14 & 0.48 & 0.39 & 0.50 & 0.50 & 0.43 & 0.48 & 0.50 & 0.50 & 0.42 & 0.60 & 0.42 & 0.53 & 0.53 & & & & & & & \\
\hline 15 & 0.42 & 0.53 & 0.61 & 0.50 & 0.36 & 0.42 & 0.50 & 0.50 & 0.41 & 0.62 & 0.28 & 0.43 & 0.54 & 0.45 & & & & & & \\
\hline 16 & 0.41 & 0.52 & 0.59 & 0.54 & 0.35 & 0.41 & 0.54 & 0.54 & 0.50 & 0.64 & 0.45 & 0.41 & 0.52 & 0.48 & 0.43 & & & & & \\
\hline 17 & 0.28 & 0.36 & 0.48 & 0.36 & 0.21 & 0.28 & 0.48 & 0.42 & 0.39 & 0.54 & 0.33 & 0.30 & 0.41 & 0.44 & 0.24 & 0.30 & & & & \\
\hline 18 & 0.32 & 0.45 & 0.46 & 0.46 & 0.25 & 0.32 & 0.52 & 0.33 & 0.43 & 0.58 & 0.37 & 0.33 & 0.32 & 0.42 & 0.35 & 0.33 & 0.20 & & & \\
\hline 19 & 0.47 & 0.47 & 0.53 & 0.53 & 0.42 & 0.47 & 0.53 & 0.48 & 0.50 & 0.63 & 0.41 & 0.47 & 0.47 & 0.44 & 0.44 & 0.38 & 0.27 & 0.30 & & \\
\hline 20 & 0.30 & 0.37 & 0.58 & 0.53 & 0.36 & 0.41 & 0.53 & 0.53 & 0.45 & 0.63 & 0.45 & 0.42 & 0.52 & 0.44 & 0.43 & 0.37 & 0.31 & 0.29 & 0.43 & \\
\hline
\end{tabular}

1) 1: G40001; 2: G40023; 3: G40033; 4: G40042; 5: G40063; 6: G40064; 7: G40066A; 8: G40068; 9: G40069; 10: G40084; 11: G40111; 12:G40125; 13: G40144A; 14: G40148; 15: G40157;

16: G40158; 17: G40135A; 18: G40173A; 19: G40237; 20: G40201

development of superior and high yielding tepary bean lines or for increasing genetic diversity in this and other related legume crops. Crosses conducted between genetically diverse genotypes may result in transgressive segregation because different genotypes can often fix different sets of alleles with complementary effects (Amelework et al., 2015). To date there is a limited number of tepary bean genotypes released for cultivation in dry environments or as source of genes for breeding globally. Only two improved cultivars namely: TARS-Tep 22 and TARS-Tep 32 have been developed and released with resistance to biotic and abiotic stresses in the USA (Porch et al., 2013b). Further, tepary bean introduction lines PI319443 and PI440795 have been widely used as sources of resistance to common bacterial blight in common bean breeding programs (Shi et al., 2011; 2012). Therefore, strategic crosses between selections from the genetic groups established in this study may allow identification of transgressive tepary bean populations.

\section{Materials and methods}

\section{Plant materials}

The study used 20 genetically diverse tepary bean genotypes. The germplasm was acquired form CIATColumbia which were originally assembled from different sources. Table 1 summarises the geographic origin, growth habits and grain characteristics of the tested genotypes. Therefore, the 20 genotypes evaluated in the current study were selected based on their diverse region of origin and suitable agronomic traits.

\section{DNA extraction, purification and quantification}

Seed of 20 genetically diverse tepary bean genotypes were planted in 4 litre capacity polyethylene pots under glasshouse conditions at the Controlled Environment Facility (CEF), University of KwaZulu-Natal (Pietermaritzburg (29³7'51.75" S; 30²3'59.10" E), South Africa.

Young fresh leaves were harvested from 5 individual plants per genotype four weeks after planting. The leaf samples were sent to INCOTEC PROTEIOS laboratory (Incotech, Pty Ltd, Pietermaritzburg, South Africa) for SSR analysis. DNA was extracted using the standard CTAB protocol (mixed alkyltrimethyl-ammonium bromide) as described by CIMMYT (2005). The concentration of the extracted DNA was determined using $0.7 \%$ Tris-Borate-EDTA (TBE) agarose gel.

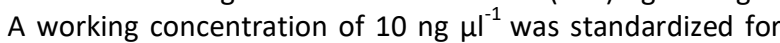
all extracted DNA. The samples were bulked and used in SSR amplification. 


\section{PCR and SSR analysis}

SSR sequences were amplified through polymerase chain reaction (PCR) using SSR primers. Ten selected and polymorphic SSR primers were used for the analysis (Table 2). The markers were selected based on their high polymorphic information content and being effective for common bean and tepary beans (Blair et al., 2003; 2006; 2012). There are no SSR primers developed specifically for tepary bean. The PCR amplification was performed using $25 \mu \mathrm{l}$ containing $25 \mathrm{ng}$ genomic DNA, $0.5 \mu \mathrm{M}$ forward and reverse primers, $25 \mathrm{mM} \mathrm{MgCl} 2,1 \times$ PCR reaction buffer, $200 \mu \mathrm{M}$ dNTPs and 1 unit of Taq DNA polymerase (Bioline). PCR products were fluorescently labelled and separated by capillary electrophoresis on an ABI 3130 automatic sequencer (Applied Biosystems, Johannesburg, South Africa). The PCR fragment size analysis was performed using GeneMapper 4.1 (Applied Biosystems, Johannesburg, South Africa).

\section{Data analysis}

\section{Genetic parameters estimates}

Genetic diversity parameters, such as number of alleles per locus $\left(\mathrm{N}_{\mathrm{a}}\right)$, number of effective alleles per locus $\left(N_{e}\right)$, observed $\left(H_{o}\right)$ and expected $\left(H_{e}\right)$ heterozygosity major allele and major allele frequency were calculated using GenAlex version 6.5 (Peakall and Smouse, 2012) according to the protocol described by Nei and Li (1979). Fixation index or inbreeding coefficient $\left(F_{\mid S}\right)$ was calculated according to Wright's original derivation (Wright, 1951). Polymorphic information content (PIC) was calculated using the formula: $P I C=1-\sum P_{i j}{ }^{2}$, where $P_{i j}$ is the frequency of $j^{\text {th }}$ allele of the $i^{\text {th }}$ locus. Pair-wise Nei's unbiased genetic distance was also estimated among the genotypes according to Nei (1978).

\section{Cluster and genetic distance analyses}

Genetic relationships among tepary bean genotypes were determined using the neighbor-joining algorithm using the unweighted pair group method of arithmetic mean (UPGMA) in DARwin 6.5 (Peakall and Smouse, 2012). The dendogram was generated based on Jaccard's dissimilarity matrix using binary data ( $0=$ absent and $1=$ present) to capture all the alleles amplified. Bootstrap analysis was performed for node construction using 10,000 bootstrap values to estimate the reliability of the clustering pattern. A cophenetic value matrix of the UPGMA clustering was used to test for the goodness-of-fit of the clustering to the resemblance matrix on which it was conducted, by computing the product-moment correlation coefficient $(r)$ with 1000 permutations (Rohlf and Fisher, 1968; Sneath and Sokal, 1973).

\section{Conclusion}

The use of common bean derived SSR markers proved highly informative suggesting their effectiveness in detecting genetic differences among the studied tepary bean genotypes. Unique genotypes such as G40201, G40237, G40158, G40157 and G40158 from Cluster I, G40084 and G40033 from Cluster III were selected based on their high genetic distance. These are recommended as parents for further breeding and to broaden the genetic basis of this crop or related legumes.

\section{Acknowledgements}

The University of KwaZulu-Natal (UKZN) and the National Research Foundation (NRF) of South Africa are acknowledged for financial support of this study.

\section{References}

Amarteifio JO, Moholo D (1998) The chemical composition of four legumes consumed in Botswana. J Food Comp Anal. 11: 329-332.

Amelework B, Shimelis $H$, Tongoona $P$, Laing $M$, Mengistu $F$ (2015) Genetic variation in lowland sorghum (Sorghum bicolor (L.) Moench) landraces assessed by simple sequence repeats. Plant Genet Resour. 13: 131-141.

Ali Z, Yao K, Odeny D, Kyalo M, Skilton R, Eltahir I (2015) Assessing the genetic diversity of cowpea [Vigna unguiculata (L.) Walp.] accessions from Sudan using simple sequence repeat (SSR) markers. Afr J Plant Sci. 9: 293-304.

Beebe S, Ramirez J, Jarvis A, Rao IM, Mosquera G, Bueno JM, Blair W (2011) Genetic improvement of common beans and the challenges of climate change. In: Yadav SS, Redden RJ, Hatfield JL, Lotze-Campen H, Hall AE (eds) Crop Adaptation to Climate Change. John Wiley and Sons, Ltd., Blackwell Publishing Ltd.

Beebe SE, Rao IM, Blair MW, Acosta-Gallegos JA (2013) Phenotyping common beans for adaptation to drought. Front Physiol. 35: 1- 20.

Bhardwaj HL, Hamama AA (2004) Protein and mineral composition of tepary bean. HortScience. 39: 1363-1365.

Bhardwaj HL, Hamama AA (2005) Oil and fatty acid composition of tepary bean seed. HortScience. 40: 14361438.

Blair MM, Munoz LC, Debouck D (2002) Tepary beans ( $P$. acutifolius): Molecular analysis of a forgotten genetic resource for dry land agriculture. Grain Leg. 36: 25-26.

Blair MW, Pedraza F, Buendia HF, Gaitán-Solís E, Beebe SE, Gepts P, Tohme J (2003) Development of a genome-wide anchored microsatellite map for common bean (Phaseolus vulgaris L.). Theor Appl Genet. 107: 1362-1374.

Blair MW, Giraldo MC, Buendía HF, Tovar E, Duque MC, Beebe SE (2006) Microsatellite marker diversity in common bean (Phaseolus vulgaris L.). Theor Appl Genet. 113: 100-109.

Blair MW, Pantoja W, Muñoz CL, (2012) First use of microsatellite markers in a large collection of cultivated and wild accessions of tepary bean (Phaseolus acutifolius A. Gray). Theor Appl Genet. 125: 1137-1147.

Buhrow R (1983) The wild beans of southwestern North America. Desert Plants 5: 67-88.

Chauhan DK, Bhat JA, Thakur AK, Kumari S, Hussain Z, Satyawathi CT (2015) Molecular characterization and genetic diversity assessment in soybean [Glycine max (L.) Merr.] varieties using SSR markers. Ind J Biotechnol. 14: 504-510.

CIMMYT (2005) Laboratory Protocols: CIMMYT applied molecular genetics laboratory 3rd edn. CIMMYT, Mexico. 
Díaz LM, Blair MW (2006) Race structure within the Mesoamerican gene pool of common bean (Phaseolus vulgaris L.) as determined by microsatellite markers. Theor Appl Genet. 114: 143-154.

Dias PMB, Julier B, Sampoux JP, Barre P, Dall'Agnol M (2008) Genetic diversity in red clover (Trifolium pratense L.) revealed by morphological and microsatellite (SSR) markers. Euphytica. 160: 189-205.

Freytag GF, Debouck DG (2002) Review of taxonomy, distribution and ecology of the genus Phaseolus (Leguminosae-Papilionoideae) in North America, Mexico and Central America. Sida Bot Misc. 23: 1-300.

Garvin DF, Weeden NF (1994) Isozyme evidence supporting a single geographic origin for domesticated tepary bean. Crop Sci. 34: 1390-1395.

Gujaria-Verma N, Ramsay L, Sharpe AG, Sanderson LA, Debouck DG, Tar'an B, Bett KE (2016) Gene-based SNP discovery in tepary bean (Phaseolus acutifolius) and common bean ( $P$. vulgaris) for diversity analysis and comparative mapping. BMC Genomics. 17: 239.

Kusolwa P, Myers J (2011) Seed storage proteins ARL2 and its variants from the apalocus of wild tepary bean $\mathrm{G} 40199$ confers resistance to Acanthoscelides obtectus when expressed in common beans. Afr Crop Sci J. 19: 255-265.

Liu S, Yu K, Park SJ (2008) Development of STS markers and QTL validation for common bacterial blight resistance in common bean. Plant Breed. 127: 62-68.

Melchinger $A E$, Messmer $M M$, Lee $M$, Woodman WL, Lamkey KR (1991) Diversity and relationships among U.S. maize inbreds revealed by Restriction Fragment Length Polymorphisms. Crop Sci. 31: 669-678.

Miklas PN, Santiago J (1996) Reaction of Select tepary bean to bean golden mosaic virus. HortScience. 31: 430-432.

Miklas PN, Kelly JD, Beebe SE, Blair MW (2006) Common bean breeding for resistance against biotic and abiotic stresses: From classical to MAS breeding. Euphytica. 147: 105-131.

Molosiwa OO, Kgokong SB, Makwala B, Gwafila C, Ramokapane MG (2014) Genetic diversity in tepary bean (Phaseolus acutifolius) landrace grown in Botswana. J Plant Breed Crop Sci. 6: 194 - 199.

Mujaju C, Sehic J, Werlemark G, Garkava-Gustavsson L, Fatih M, Nybom H (2010) Genetic diversity in watermelon (Citrullus lanatus) landraces from Zimbabwe revealed by RAPD and SSR markers. Hereditas. 147: 142-153.

Muñoz LC, Blair MW, Duque MC, Tohme J, Roca W (2004) Introgression in common bean $\times$ tepary bean interspecific congruity-backcross lines as measured by AFLP Markers. Crop Sci. 44: 637-645.

Muñoz LC, Duque MC, Debouck DG, Blair MW (2006) Taxonomy of tepary bean (Phaseolus acutifolius) and wild relatives as determined by amplified fragment length polymorphism (AFLP) markers. Crop Sci. 46: 1744-1754.

Nei M, Li W (1979) Mathematical method for studying genetic variation in terms of restriction endonucleases. Proc Natl Acad Sci USA. 76: 5256-5273.

Nei M (1978) Estimation of average heterozygosity and genetic distance from a small number of individuals. Genet Mol. Rep. 89: 583-590.

Oteng-Frimpong R, Sriswathi M, Ntare BR, Dakor F (2015) Assessing the genetic diversity of 48 groundnut (Arachis hypogaea L.) genotypes in the Guinea savanna agro- ecology of Ghana, using microsatellite-based markers. Afr J Biotechnol. 14: 2485-2485.

Peakall R, Smouse PE (2012) Genetic analysis in Excel. Population genetic software for teaching and research- an update. Bioinformatics. 28: 2537-2539.

Peng JH, Fahima T, Röder MS, Li YC, Dahan A, Grama A, Ronin $\mathrm{Yl}$, Korol AB, Nevo E (1999) Microsatellite tagging of the stripe-rust resistance gene $\mathrm{YrH} 52$ derived from wild emmer wheat, Triticum dicoccoides, and suggestive negative crossover interference on chromosome 1B. Theor Appl Genet. 98: 862-872.

Pratt RC, Nabhan GP (1988) Evolution and diversity of Phaseolus acutifolius Gray genetic resources. In: Gepts P (ed) Genetic resources of Phaseolus beans, Kluwer, Dordrecht, Netherlands.

Porch TG, Beaver JS, Debouck DG, Jackson SA, Kelly JG, Dempewolf H (2013a) Use of wild relatives and closely related species to adapt common bean to climate change. Agronomy. 3: 433 - 461.

Porch TG, Beaver JS, Brick MA (2013b) Registration of tepary germplasm with multiple-stress tolerance, TARS-Tep 22 and TARS-Tep 32. J Plant Reg. 7: 358-364.

Rebaa F, Abid G, Aouida M, Abdelkarim S, Aroua I, Muhovski Y, Baudoin JP, M'hamdi M, Sassi K, Jebara M (2017) Genetic variability in Tunisian populations of faba bean (Vicia faba L. var. major) assessed by morphological and SSR markers. Physiol Mol Biol Plants. 23: 397-409.

Rao I, Beebe S, Polania J, Ricaurte J, Cajiao C, Garcia R, Riverra M (2013) Can tepary bean be a model for improvement of drought resistance in common bean? Afr Crop Sci J. 21: $265-281$.

Rohlf FJ, Fisher DL (1968) Test for hierarchical structure in random data sets. Syst Biol. 17: 407-412.

Schinkel C, Gepts P (1988) Phaseolin diversity in the tepary bean, Phaseolus acutifolius A. Gray. Plant Breed. 101: 292301.

Shi C, Navabi A, Yu K (2011) Association mapping of common bacterial blight resistance QTL in Ontario bean breeding populations. BMC Plant Biol. 11: 52.

Shi C, Yu K, Xie W, Perry G, Navabi A, Peter P, Miklas, PK, P.N., Fourie, D (2012) Development of candidate gene markers associated to common bacterial blight resistance in common bean. Theor Appl Genet. 125: 1525-1537.

Souter JR, Gurusamy V, Porch TG, Bett KE (2017) Successful introgression of abiotic stress tolerance from wild tepary bean to common Bean. Crop Sci. 57: 1160-1171.

Singh SP, Muñoz CG (1999) Resistance to common bacterial blight among Phaseolus species and common bean improvement. Crop Sci. 39: 80-89.

Sneath P, Sokal R (1973) Numerical Taxonomy: The principles and practice of numerical classification. S. W. Freeman, San Francisco, CA.

Smith JSC, Kresovich S, Hopkins MS, Mitchell SE, Dean RE, Woodman WL, Lee M, Poster K (2000) Genetic diversity among elite sorghum inbred lines assessed with simple sequence repeats. Crop Sci. 40: 226-232.

Tar'an B, Michaels TE, Pauls KP (1998) Stability of the association of molecular markers with common bacterial blight resistance in common bean (Phascolus vulgaris L.). Plant Breed. 117: 553-558.

Thomas CV, Manshhardt RM, Waines JG (1983) Teparies as a source of useful traits for improving common bean. Desert Plants. 5: 43-48. 
Varshney RK, Graner A, Sorrells ME (2005) Genic microsatellite markers in plants: features and applications. Trends Biotechnol. 23: 48-55.

Wright S (1951) The genetical structure of populations. Annals Eugen. 15: 323-354.

Xu P, Wu X, Luo J, Wang B, Liu Y, Ehlers JD, Lu Z, Li G (2011) Partial sequencing of the bottle gourd genome reveals markers useful for phylogenetic analysis and breeding. BMC Genomics 12: 467-417.

Xu S, Wang G, Mao W, Hu Q, Liu N, Ye L, Gong Y (2014) Genetic diversity and population structure of common bean (Phaseolus vulgaris) landraces from China revealed by a new set of EST-SSR markers. Biochem Syst Ecol. 57: 250-256 